\title{
SOMATOSTATIN (D-) CELLS IN THE RAT PYLORIC ANTRUM, WITH SPECIAL REFERENCE TO THE DESTINATION OF THEIR CYTOPLASMIC PROCESSES
}

\author{
Yoshisuke Kusumoto and Dietrich Grube \\ Abteilung Anatomie 1 der Medizinischen Hochschule Hannover, Hannover, F.R.G.
}

\begin{abstract}
Somatostatin from gastric D-cells exerts inhibitory effects upon acid secretion and gastrin release. From previous morphological investigations, a paracrine mode of action of somatostatin (secretion into the intercellular space) has been postulated. However, the exact route of delivery of gastric somatostatin remains uncertain. To obtain a closer view of gastric D-cells, their whole shape and their microanatomical relationship were examined in immunostained serial semithin $(0.5 \mu \mathrm{m})$ sections of the rat pyloric mucous membrane. A minority of D-cells was found to belong to the 'closed-type' entero-endocrine cells which showed no contiguity to the luminal surface. The majority of D-cells was of the 'open-type'. Every D-cell had one (or exceptionally two) basally located and densely immunostained cytoplasmic process which never branched. All these processes regularly extended to capillaries. Only three of fifty D-cells examined were located adjacent to gastrin (G-) cells. Thus, somatostatin may act upon gastric $G$-cells via a local circulatory system rather than by a paracrine mode of action. Finally, a subpopulation of gastric $\mathrm{D}$-cells was detected which, according to cytological parameters, may also secrete into the gastric lumen. This kind of $\mathrm{D}$-cells seems responsible for the presence of somatostatin in the gastric juice.
\end{abstract}

Somatostatin is a peptide common to the nervous and endocrine systems and universally occurs in the organism (for recent reviews, see $25,27,28$ ). Within the gastroentero-pancreatic (GEP) endocrine system, somatostatin is localized in D-cells of the endocrine pancreas and the gastrointestinal epithelia $(7,20,22,30)$. In the stomach, the main function of somatostatin seems to inhibit acid secretion and gastrin release $(25,27$, 28). Previous morphological investigations on gastric D-cells have shown that these cells

Reprint requests to: Dr Yoshisuke Kusumoto, Department of Anatomy, Hiroshima University School of Medicine, 1-2-3 Kasumi, Minami-ku, Hiroshima 734, Japan have long cytoplasmic processes which obviously extend to presumed 'target cells' (2, $16,21)$. Therefore, D-cells have served as a paradigm for Feyrter's concept of 'paracrinia', i.e. the local regulation of organ's function (4). A further peculiarity of D-cells and their secretion product is related to the observation that somatostatin is also found in the gastric juice $(1,34)$. This is the reason why somatostatin has also been denóminated as a 'lumone' (28). Hence, mainly paracrine or exocrine pathways have been considered for the delivery of somatostatin to its target cells, but its exact route has remained uncertain.

The present study was designed to answer this question. Whereas former morphological investigations in this field have been per- 
formed with paraffin and cryostat sections or with single thin sections, we now investigated immunostained serial semithin sections. This technique is appropriate to give a detailed morphological image of endocrine cells and of their microanatomical relationships to neighbouring structures $(11,15)$.

Our findings favor the conclusion that gastric antral somatostatin is mainly delivered by an endocrine route.

\section{MATERIALS AND METHODS}

\section{Tissue Preparation}

Small specimens from the antropyloric mucosa of 3 adult Wistar rats were frozen in melting Freon 22 at $-150^{\circ} \mathrm{C}$, freeze-dried, fixed by vapor-phase paraformaldehyde, and embedded in epoxy resin (Araldite). Serial semithin sections were cut at $0.5 \mu \mathrm{m}$ and mounted on microscopic slides (for details, see 11).

\section{Immunohistochemistry}

After removal of the resin by sodium methoxide, the sections were immunostained by the peroxidase anti-peroxidase technique (31) as modified for semithin sections $(8,11)$. The antisera used as first layers were anti-somatostatin (gift of Dr Etzrodt, Ulm, F.R.G.), antigastrin (from Dr Schlegel, Münster, F.R.G.), and anti-serotonin (from Euro Diagnostics, The Netherlands). Working dilutions of these antisera were $1: 4,000$. The other steps of the immunohistochemical protocol and appropriate specificity controls were performed as described previously $(8,11)$. The sections were mounted without counterstaining and viewed by phase contrast or interference contrast in a Leitz Orthoplan microscope.

\section{Analysis of Serial Sections}

Series of 50-100 semithin sections were either immunostained exclusively by anti-somatostatin or sequentially by anti-somatostatin, anti-gastrin, or anti-serotonin.

In series immunostained exclusively for somatostatin, the shape of single D-cells, the intracellular distribution of immunoreactive somatostatin, and the microanatomical relationships of D-cells to neighbouring structures were carefully examined. The topographical relationship between D-cells and gastrin (G-) cells or enterochromaffin (EC-) cells were determined in series of sections which had been immunostained alternately for the corresponding two antigens. Concerning the relationship between D- and G-cells, fifty randomly selected D-cells (in specimens of all 3 animals) were analyzed. The topographical relationship between $\mathrm{D}$-cells was examined in specimens of only one rat; thus the findings may be taken as preliminary.

\section{RESULTS}

\section{Cytologic Characteristics of D-Cells}

The majority of D-cells was located in the lower part of the pyloric glands. In single sections the shape of D-cells is racket-like, but three-dimensionally D-cells are usually flusklike. With respect to their contiguity to the luminal surface, D-cells (like other enteroendocrine cell types; see 7) could be subdivided into two basic types. A minority of cells lacked luminal contacts and was of the 'closed-type' (Fig. 1). Most of D-cells in the pyloric epithelium, however, were contiguous to the epithelial surface and belong to the 'open-type' endocrine cells. The latter kind of D-cells appears to be heterogeneous as seen by the intracellular distribution of immunoreactive somatostatin. In some D-cells, somatostatin is localized mainly in the cell apex (Fig. 2). The majority of open-type D-cells, however, shows dense immunostaining in the basal part of the cell (Fig. 3). A feature common to almost all D-cells is the cytoplasmic process which extends from the basal parts of the cell and runs along the basement membrane. These processes were regularly found to be densely immunostained (Figs. 4-9). In D-cells localized in the upper part of the pyloric glands, the

Figs. 1-3 Heterogeneity of D-cells in the pyloric glands of the rat stomach. A minority of D-cells is of the 'closed-type' and has no contiguity to the luminal surface (Fig. 1). 'Open-type' D-cells rarely show accumulation of the immunoreactive material in the cell apex (Fig. 2). The majority of open-type D-cells exhibits densely immunostained and basally located cytoplasmic processes (Fig. 3). c, capillaries; $\mathrm{L}$, Lumen of the pyloric glands. Interference contrast optics. $\times 1,100$

Figs. 4-9 Typical images of D-cells in the pyloric glands of the rat stomach. The cytoplasmic processes of D-cells located in the upper part of the mucosa (Figs. 4-7) are longer than those of D-cells located near the bottom of the glands (Figs. 8 and 9 ). In both cases, the cytoplasmic processes extend to capillaries (c). Phase contrast optics. $\times 1,000$ 

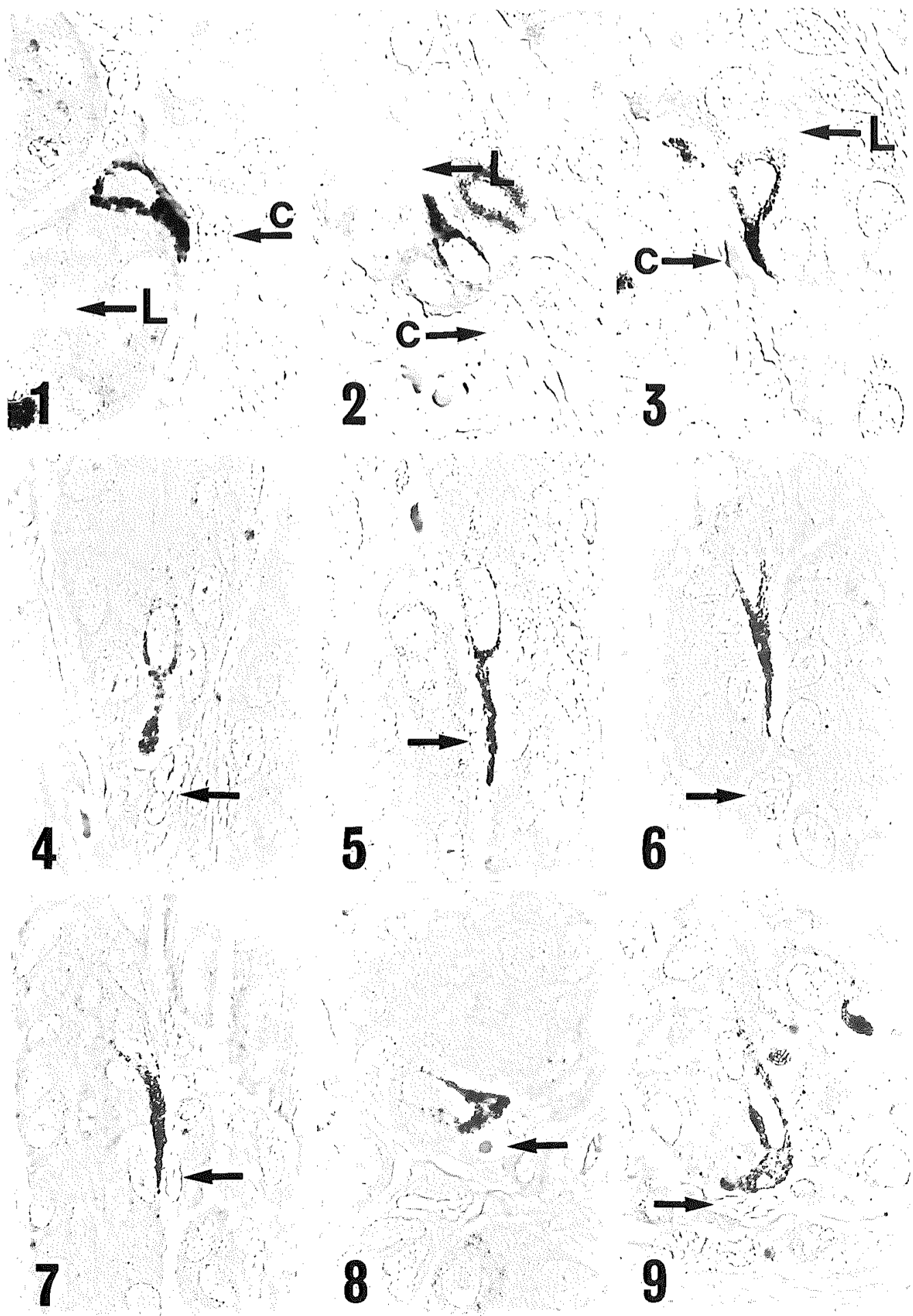

Figs. 1-9 


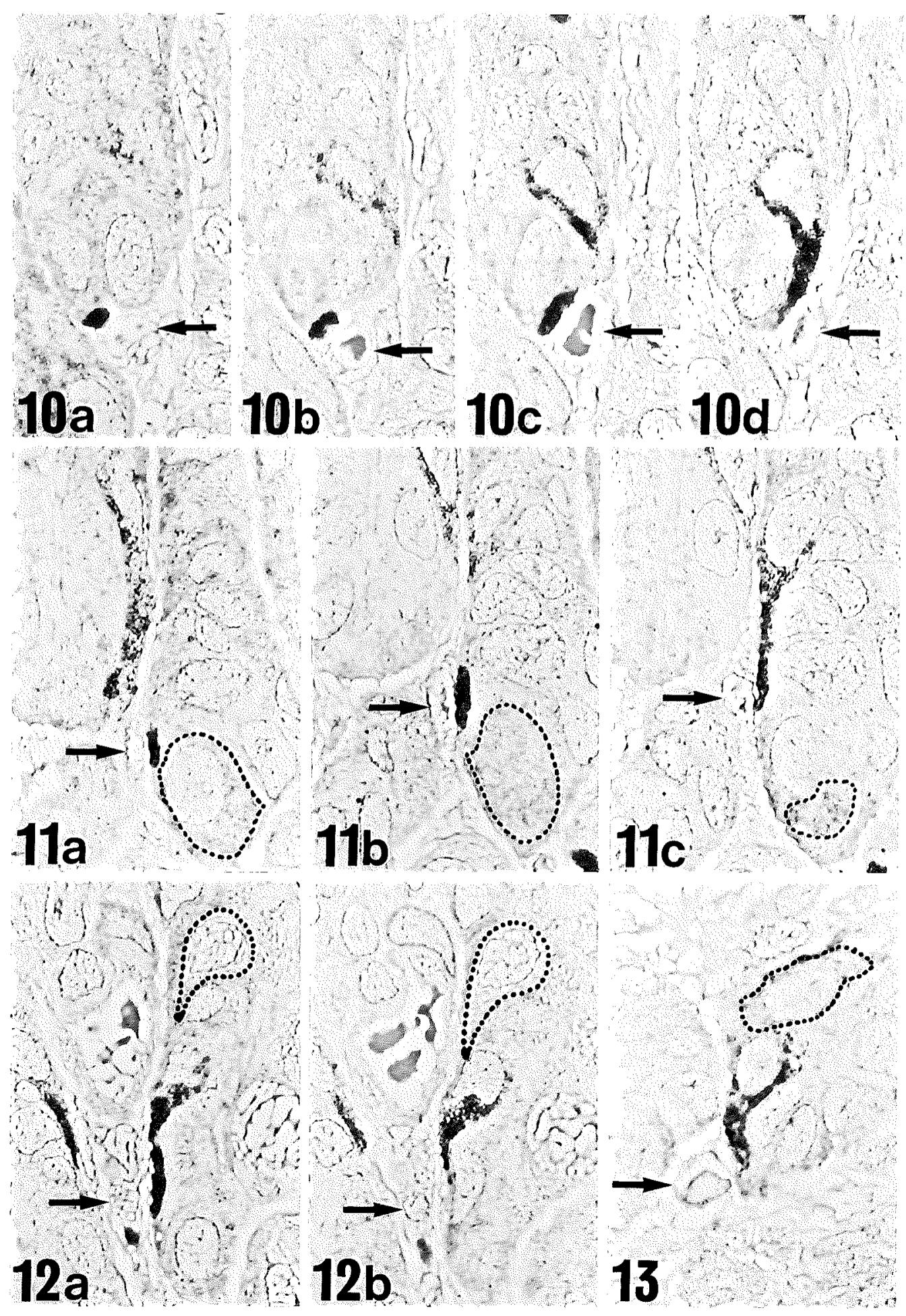

Figs. 10-13 
cytoplasmic processes tended to be longer. Usually, every D-cell had only one basal process, and the process did not show any branching.

\section{Microtopography of D-Cells}

Examinations of serially sectioned D-cells revealed that their cytoplasmic processes were regularly localized in close proximity to capillaries (Figs. 4-13). Some processes exhibited terminal swellings (Fig. 10). Considering the juxtaposition of D-and G-cells, we found that out of fifty D-cells examined only three Dcells $(6 \%)$ were localized in direct proximity to G-cells (Figs. 11-13). However, these D-cells also showed a topographical relationship to capillaries. Preliminary examinations on the mutual topographic relationship between Dcells and EC-cells gave similar results: D-cells and EC-cells were in most cases topographically segregated.

\section{DISCUSSION}

In the GEP-endocrine system, somatostatin is believed to act as a local regulatory peptide which exerts its functions mainly by interactions with adjacent target cells, i.e. in a paracrine mode of action. In the endocrine pancreas, the apparent microtopographical interposition of D-cells between insulin (B-) and glucagon (A-) cells serves as the morphological counterpart of a paracrine mode of secretion $(26,33)$. However, recent investigations have revealed that pancreatic D-cells are typical endocrine elements whose cytoplasmic processes regularly project to intra-insular

Fig. 10 Semiadjacent semithin sections through a D-cell and its basal cytoplasmic process. The process shows a terminal swelling (Fig. 10a) and extends to a capillary (arrows). Phase contrast optics. $\times 1,350$

Figs. 11-13 The three D-cells (out of fifty D-cells examined) located adjacent to gastrin (G-) cells (marked by dotted lines according to gastrin immunostaining in adjacent sections). Fig. 11: Three semiadjacent semithin sections through a D-cell and its cytoplasmic process. The process extends to a capillary (arrows) and faces also a G-cell. Fig. 12: Two semiadjacent semithin sections through a $D$ cell whose cell body is located adjacent to a G-cell. The D-cell process extends to a capillary (arrows). Fig. 13: Another D-cell facing a G-cell with its cell body and extending to a capillary (arrow) with a densely immunostained cytoplasmic process. Phase contrast optics. $\times 1,350$ capillaries (10). Therefore, pancreatic somatostatin may act rather via local portal vessels (5) or by microhemocrinia (6; see also 14$)$.

Likewise, D-cells in gastro-intestinal epithelia have so far been regarded as paracrine cells whose cytoplasmic processes ('paraxons') terminate on adjacent target cells $(19,20)$. In the pyloric glands of the stomach, the mutual topographic relationship between D-cells and G-cells attracted special attention. Here also, the inhibitory effects of somatostatin upon gastrin synthesis and release were seemingly mediated by direct cell-to-cell interactions (13, 18, 23). However, our present findings indicate that the majority of pyloric D-cells may secrete to the vascular bed. All basally located cytoplasmic processes of these cells, when examined in serial sections, were found to 'terminate' at capillary walls. In addition, every D-cell usually has, in contrast to previous suggestions (21), only one cytoplasmic process, and branching of the process is never observed. We thus conclude that pyloric Dcells, with their densely immunostained processes extending to capillaries, are also typical endocrine cells which deliver somatostatin to blood vessels. In analogy to the situation within pancreatic islets (10), somatostatin may reach its target cells either via 'short-loop mechanisms' (microhemocrinia; 6, 9) or via the systemic circulation (macrohemocrinia; $6)$. Because we and other authors $(3,17)$ only exceptionally found $\mathrm{D}$-cells in close proximity to G-cells, inhibition of the latter cells by somatostatin secreted into the intercellular space seems unlikely (see also 9).

A subpopulation of pyloric D-cells showed an intracellular distribution of immunoreactive somatostatin inverse to the usual image. In these D-cells, the apical cell part facing the luminal surface was densely immunostained. If the site of predominant accumulation of the immunoreactive material reflects the site of its delivery from the cell, these D-cells may secrete into the lumen and thus exhibit an exocrine mode of secretion. If so, apically granulated D-cells may be the source of somatostatin found in the gastric juice (34). Since the somatostatin content in the gastric juice varies under certain experimental (1) or pathological conditions (12), we further postulate that gastric D-cells are provided with certain plasticity with respect to the main route of somatostatin secretion. According to the change in metabolic state, the predominant route may change from 'endocrinia' to 
'exocrinia'. This question should be examined by further investigations with D-cells in other regions of the stomach.

Finally, factors that are possibly related to the presence of cytoplasmic processes of gastric D-cells need to be commented. For gastric $\mathrm{D}$-cells (present study) and pancreatic D-cells (10), the 'target' of the process is the capillary. Furthermore, the length of cytoplasmic D-cell processes in pyloric glands largely depends upon their location within the mucosa; Dcells in the upper part of the mucosa have longer processes. If we take into account the fundings in colonic entero-endocrine cells (32), only a 'mechanical' factor may be involved in the length of D-cell processes. Since the turnover time of entero-endocrine cells is longer than that of other epithelial cells, the migration of entero-endocrine cells towards the mucosal surface is presumed to occur independently and very slowly (32). During this migration the cell base 'adhered to the basement membrane with enough strength to be retained as a cytoplasmic process' (32). On the other hand, it has to be stressed that somatostatin cells of pancreatic (24) and of gastric origin (29) show peculiar cytoplasmic processes even when growing in culture.

Further investigations are necessary to obtain a better understanding of the mode of action of D-cells and other GEP-endocrine cells.

The authors wish to thank Ms M. Meyer, Ms H. Peesel and Mr S. Gudat for their expert technical assistance.

Received for publication 2 March 1987

\section{REFERENCES}

1. Alino S. F., Garcia D. and Uvnäs-Moberg K. (1986) Effect of intragastric pH, prostaglandins and prostaglandin synthesis inhibitors on the release of gastrin and somatostatin into the gastric lumen of anaesthetized rats. Acta Physiol. Scand. 126, 1-8

2. Alumets J., Ekelund M., El Munshid H. A., HÅKANSON R., LORÉN I. and SUNDLER F. (1979) Topography of somatostatin cells in the stomach of the rat: possible functional significance. Cell Tissue Res. 202, 177-188

3. Buchan A. M. J., Sikora L. K. J., Levy J. G., Mclntosh C. H. S., Dyck I, and Brown J. C. (1985) An immunocytochemical investigation with monoclonal antibodies to somatostatin. Histochemistry 83, 175-180
4. Feyrter F. (1953) Über die peripheren endokrinen (parakrinen) Drïsen des Menschen. Second Ed., W. Maudrich, Wien/Düsseldorf

5. Forssmann W. G., Helmstaedter V., Metz J., Mühlmann G. and Feurle G. E. (1978) Immunohistochemistry and ultrastructure of somatostatin cells with special reference to the gastroenteropancreatic (GEP) system. Metabolism 27, Suppl. 1, 1179-1191

6. Fujita T. (1983) Messenger substances of neurons and paraneurons: their chemical nature and the routes and ranges of their transport to targets. Biomedical Res. 4, 239-256

7. Fujita T. and Kobayashi S. (1977) Structure and function of gut endocrine cells. Intern. Rev. Cytol., Suppl. 6, 187-233

8. Grube D. (1980) Immunoreactivities of gastrin (G-) cells. II. Non-specific binding of immunoglobulins to $\mathrm{G}$-cells by ionic interactions. Histochemistry 66, 149-167

9. Grube D. (1986) The endocrine cells of the digestive system: amines, peptides, and modes of action. Anat. Embryol. 175, 151-162

10. Grube D. and Bohn R. (1983) The microanatomy of human islets of Langerhans, with special reference to somatostatin (D-) cells. Arch. Histol. Japon. 46, 327-353

11. Grube D. and Kusumoto Y. (1986) Serial semithin sections in immunohistochemistry: techniques and applications. Arch. Histol. Japon. 49, $391-410$

12. Harty R. F., Maico D. G. and McGuigan J. E. (1986) Antral release of gastrin and somatostatin in duodenal ulcer and control subjects. $G u t$ 27, 652-658

13. Helmstaedter V., Feurle G. E. and ForssMANN W. G. (1977) Relationship of glucagonsomatostatin and gastrin-somatostatin cells in the stomach of the monkey. Cell Tissue Res. 177, 29-46

14. Kawai K., Ipp E., Orci L., Perrelet A. and UNGer R. H. (1982) Circulating somatostatin acts on the islets of Langerhans by way of a somatostatin-poor compartment. Science 218, 477-478

15. Kusumoto Y. and Grube D. (1986) Cytological characteristics of enteroendocrine cells. Acta Anat. Nippon 61, 380, (English abstract)

16. Kusumoto Y., Iwanaga T., Ito S. and Fujita T, (1979) Juxtaposition of somatostatin cell and parietal cell in the dog stomach. Arch. Histol. Japon. 42, 459-465

17. Lamberts R. and Creutzfeldt W. (1986) Topographical relationship of the antral somatostatin cell: an immunoelectron microscopical study. Acta Endocrinol. 111, Suppl. 274, 31-32

18. Larsson L.-I. (1980) Peptide secretory pathways in GI tract: cytochemical contributions to regulatory physiology of the gut. Amer. $J$. Physiol. 239, G237-G246

19. LaRsson L.-I. (1984) Evidence for anterograde transport of secretory granules in processes of 
gastric paracrine (somatostatin) cells. Histochemistry 80, 323-326

20. Larsson L.-I. (1985) Distribution and morphology of somatostatin celis. Adv. Exp. Med. Biol. 188, 383-402

21. Larsson L.-I., Goltermann N., De Magistris L., Rehfeld J. F, and Schwartz T. W. (1979) Somatostatin cell processes as pathways for paracrine secretion. Science 205, 1393-1394

22. Leclerc R., Pelletier G., Puviani R., Arimura A. and Schally A. V. (1976) Immunohistochemical localization of somatostatin in endocrine cells of the rat stomach. Mol. Cell. Endocrinol. 4, 257-261

23. Lehy T., Grès L. and De Castro E. F. (1979) Quantitation of gastrin and somatostatin cell populations in the antral mucosa of the rat. Comparative distribution and evolution through different life stages. Cell Tissue Res. 198, 325-333

24. Matsuba I., Tanese T. and Abe M. (1982) Human pancreatic islet cell clones secreting insulin, glucagon and somatostatin: immunocytochemical and functional studies. Arch. Histol. Japon. 45, 111-119

25. McIntosh C. H. S. (1985) Gastrointestinal somatostatin: distribution, secretion and physiological significance. Life Sci. 37, 2043-2058

26. OrCi L. and Unger R. H. (1975) Functional subdivision of islets of Langerhans and possible role of D cells. Lancer II, 1243-1244

27. Patel Y. C. and Tannenbaum G. S. (1985) Somatostatin, Plenum Press, New York

28. Reichlin S. (1983) Somatostatin. New Engl. J.
Med. 309, 1495-1501 and 1556-1563

29. Sahondramanarivo G., Hollande E., PequigNOT J., ACCARY J.-P. and Dubrasquet J.-M. (1986) Mucus, gastrin and somatostatin cells in cultured rat antral mucosa: immunofluorescence, ultrastructural and radioimmunological studies. Gastroenterol. Clin. Biol, 10, 211219

30. Solcia E., Creutzfeldt W., Falkmer S., Fujita T., Greider M. H., Grossmann M. I., Grube D., HÅKanson R., LarsSon L.-I., Lechago J., Lewin K., PolaK J. M. and Rubin W. (1981) Human gastroenteropancreatic endocrine-paracrine cells: Santa Monica 1980 classification. In Cellular Basis of Chemical Messengers in the Digestive System (ed. Grossman M. I., Brazier M. A. B. and Lechago J.) Academic Press, New York, pp. 159-165

31. Sternberger L. A. (1986) Immunocytochemistry Third Ed., John Wiley \& Sons, New York

32. Tsubouchi S. and Leblond C. P. (1979) Migration and turnover of entero-endocrine and caveolated cells in the epithelium of the descending colon, as shown by radioautography after continuous infusion of ${ }^{3} \mathrm{H}$-thymidine into mice. Amer. J. Anat. 156, 431-452

33. Unger R. H. and Orci L. (1977) Possible roles of the pancreatic D-cell in the normal and diabetic states. Diabetes 26, 241-244

34. Uvnäs-Wallensten K., Efendic S. and Luft R. (1977) Vagal release of somatostatin into the antral lumen of cats. Acta Physiol. Scand. 99, $126-128$ 